\title{
THE NECESSITY OF THE REGIONAL EMPLOYMENT POLICY
}

\author{
Katalin Lipták Ph.D. \\ assistant lecturer \\ Faculty of Economics, University of Miskolc \\ E-mail: $\underline{\text { liptak.katalin@uni-miskolc.hu }}$
}

\begin{abstract}
I assume that globalization and its regional and local impacts have an important role in nowadays' economics. Paradoxically, challenges arising from the unification of the world have made the necessity for regional and local answers stronger. The transformation of the labour market calls for the revaluation of the notion of labour; it puts the issue of employment in another perspective. The solution for globally existing lack of employment is more and more frequently sought focusing on sustainability and social inclusion at regional and local levels.
\end{abstract}

Keywords: labour market, Central-Eastern-Europe, regional employment policy, regional disparities

JEL classification: $\mathrm{J} 21, \mathrm{R} 23$

\section{Introduction}

The employment policy of the European Union significantly determines and sets limits on the employment-related objectives and efforts of the nation states. There is no experience of regionally differentiated employment policy in Hungary. No examples can be found to this in Europe either, however, the existence of a regional employment policy with be reasonable. I analysed the aims and employment policy tools by the Central-European countries' employment policies and I try to give some recommendations for a regional employment policy in Hungary.

\section{Labour concept of the post-industrial societies}

Modern societies are rightly called the "society of paid work", however the term "labour society" also appears frequently in the literature. One can read about the crisis of paid work since the 1960s, its heyday was the first quarter century up until the first oil crisis. The crisis was not only about the change and transformation of the world of work, it was also about the atypical forms of employment becoming increasingly popular. Part of the society was excluded from the world of paid work after the period of industrialization, it can be regarded as nowadays' period as well. The beginning of the crisis of labour paradigm started with Arendt's (2002) statement: "what is ahead of us is a labour society that is running out of work that is from the only activity it is good at. What could be more terrible than that?" He likens paid work to slave work and not to a voluntarily undertaken activity of free man. Gorz suggested that the socially useful activity should be placed at the centre of the society instead of paid work. Beck spoke of civic work done in favour of the community (Csoba 2010).

It can be seen that the concept of paid work is gradually loosing that of labour, which is a considerable problem. The re-definition of paid work is necessary because a significant part of the society has been excluded from the classical paid work. 
A smaller proportion of people of working age works in one of the traditional forms of employment, atypical forms of employment can be regarded as typical in the developed European countries, since they dominate.

\section{The new solutions on the labour market}

Before the regime change by the Central-European counties, almost $90 \%$ of the employee had "traditional" fix-term labour contract, which legal regulation was involved in the Labour Code. Besides, contracts of agency and of work fallen under the Civil Code were also present in business. Moreover, there were atypical forms of employment as well, that differed from typical, but the rate of these was negligible in view of the employment ratios of the national economy. So their application was not really widespread due to the lack of the necessary legal background.

The situation significantly changed after the transition to market economy. Both employers and employees gave up the former attitude. Before the transition the traditional employment meant safety for the employee. One of the disadvantages of the atypical forms of employment is that the employer's interest comes into the limelight and in contradiction to the interest of the employee, which leads to a more uncertain situation for the employee. The appearance and spread of atypical forms of employment was caused by the different environmental conditions, that is a brand new form of enterprises and mass unemployment appeared and new tax categories were introduced. As everything that is new or innovative, it arose strong repugnance first, but later its advantages and application conditions were more and more discovered. It was accompanied by the formation of the legal background and its adaption to the European trends, which was even more affected by the joining to the European Union in 2004.

The appearance of atypical forms of employment was also enhanced by the facts that the characteristics of labour changed in the long run, markets became more and more unstable and information technology gradually spread. In the capitalist economy in its traditional sense, traditional employment functioned well, but in the economics with new characters, the formation and spread of employment different from traditional were necessary. Companies need to be able to modify the labour force flexible. To do so, employee does not need to be dismissed, instead, temporary employment can be applied. (Ékes 2009) According to Héthy (2001), the effect of the globalization to the employers and the employees can be summed as follows: the traditional employment for an unlimited time is replaced by fixed-duration employment, the utilization of working hours become more flexible, working without employment (based on civil legal relations) comes into the limelight, part-time employment spreads instead of full-time employment and as a result of all this atypical employment spreads. The most important types of atypical employment applied in Hungary as well are presented below.

\section{Teleworking}

"Teleworking is usually ranked as an atypical form of employment because of the atypical characteristic of the place of working... According to the broadest definition, telework is each work when the employer and the employee are far from each other. In a narrow sense, telework is the work within the work organization that is independent of the traditional organizational characteristics in time and space." (Kiss 2001, 460.)

The employee does not work in a work organization and there is a telecommunication link between him/her and the employer. Telework is done among domestic circumstances, not at the 
actual premises or headquarter of the company. Through information conditions it can be worked out without any problems. The employer is responsible for the arrangement, the precise definition of the work and (s)he can also check the produced result.

\section{Part-time working}

There is no exclusive definition for part-time working in international legal sources. According to the ILO definition part-time working is "significantly shorter than the normal working hours". OECD - primarily because of statistical reasons - uses the definition of working hours less than 30 hours weekly. The EU directive about part-time working defines part-time employee as the one who is employed for shorter working hours than full-time employee at the same workplace.

\section{Temporary employment}

Temporary employment is a special form of working established to reduce costs. In this case the employer who signs the labour contract with the employee and the actual employer are not the same. It is important that - because of guarantee reasons - only those employees can be borrowed that were employed especially for this reason. Other employee cannot get into this situation because of the employer's decision. That is why only companies meeting some specific conditions can deal with temporary employment. In Hungary, for example they have to be registered in order to be able to start working.

Temporary employment is an interesting issue on its own. In the recent economic crisis, you can hear about staff work force reductions in the daily news, but temporary employment can hardly be heard. Let us take into consideration that in the crisis, companies first give up borrowed employee. They give him/her a notice or do not extend the fixed-duration contracts. These are, however, done simply, without "propaganda", even if they have a great sway. Temporary employment is one of the most widespread atypical forms of employment in Hungary.

Limited available statistical data about temporary employment has to be handled gingerly as they do not exactly reflect the truth. Answers cannot be found from the data to important questions like how many people are regularly employed by borrowing companies. It is not known, furthermore, how satisfied they are with the employees and how many days the employees spend at the given company. Only an increasing or a decreasing trend is known. Because of these reasons, statements that temporary employment can efficiently contribute to making the labour market more efficient has to be handled gingerly. It cannot be denied, however, that this represents the largest proportion among atypical forms of employment.

Atypical employment would be a good opportunity for Central Eastern European countries to improve their employment situation. In the meantime, however, these are the problems of the labour market for which finding solutions is the most difficult. Economic crisis has affected atypical forms of employment significantly as well, even if these would be a way to escape for people crowded out from the labour market. It requires a change of approach in the case of the employers and the employee. Atypical forms of employment cannot be considered as typical, widely used practice in the case of Central Eastern European countries.

The spread of atypical forms of employment can be promoted by the increasing willingness of women to work, the relatively long term unemployment (which unfortunately exists nowadays 
as well due to the crisis), the income earning strategies of the employee adopted to the individual life cycles. (Lipták 2011)

\section{Analysis the Beveridge-curve - methodology and results}

According to the basic theorem of neoclassical macro-economics the equilibrium rate of unemployment corresponds to the natural rate in reality as well, that is, unemployment is frictional in nature in the long term. One tool to study natural rate is Beveridge-curve (or UVcurve) that shows the connection between the unemployment and job-vacancy (underutilization) ratios (Galasi 1994). The curve was first created by co-authors Dow and DicksMireaux (1958). Their analysis revealed negative connection between $\mathrm{V}$ and $\mathrm{U}$ that they interpreted that if an economy is in recession and unemployment is high than there are few vacant jobs and it is true vice-versa as well. They also found data that do not fit with this hyperbolic curve. They thought it was because a measurement error due to the fact that actual vacant jobs cannot be adequately accounted for (Rodenburg 2007). The underutilization rate equals the number of actual vacant (empty) job divided the number of employed people.
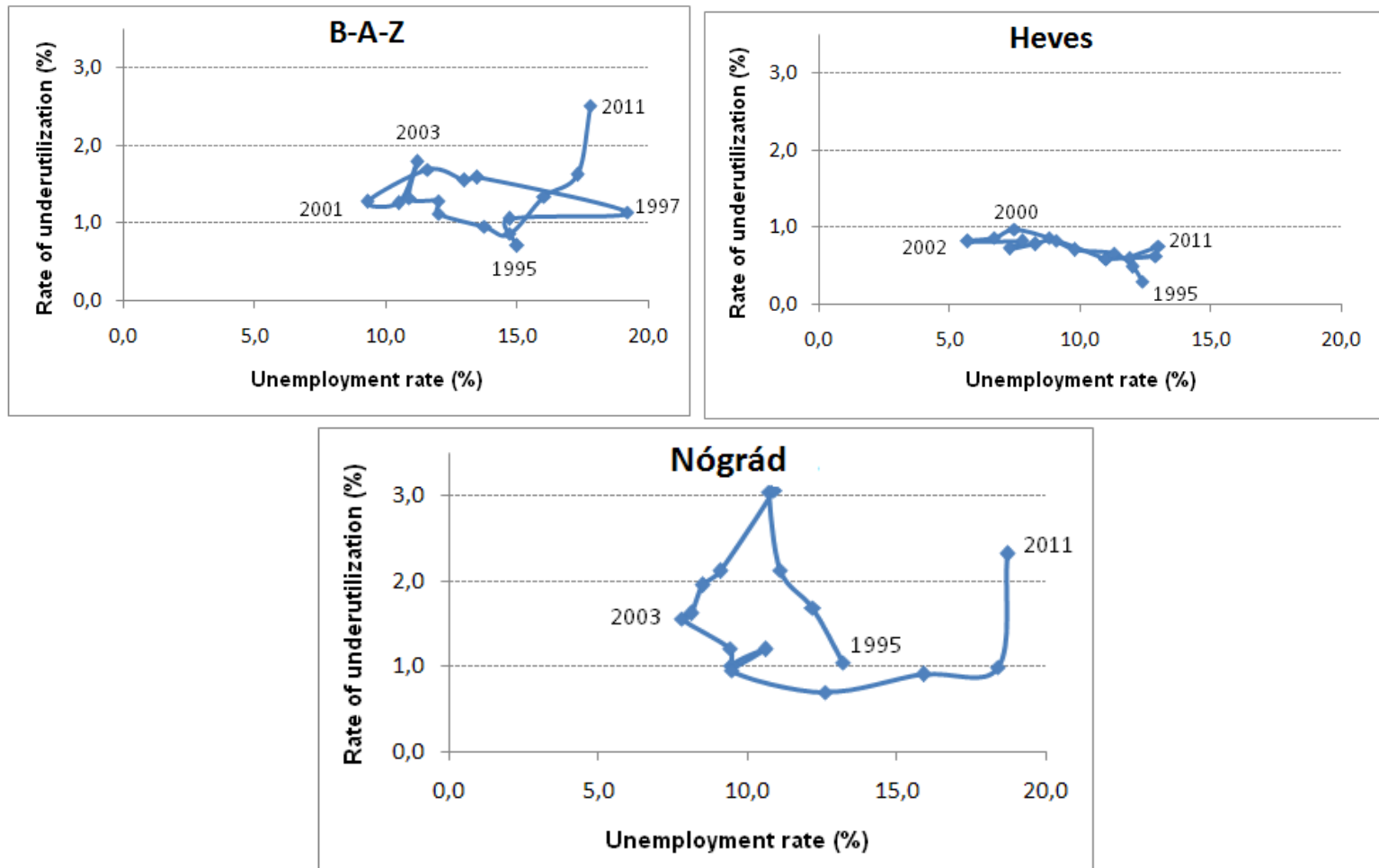

Figure 1: Evolution of Beveridge-curve between 1995 and 2011 by counties of Northern

Source: Own work, 2013

Hungarian region

Among the regions of Northern Hungary, Beveridge-curve indicated the smallest change in Heves County, that is, the state in year 2011 was almost the same as that in 1995. The County's labour market was in the best condition in 2002. The shape of the curve is much mor hectic in the case of Borsod-Abaúj-Zemplén and Nógrád Counties, the unemployment rate has significantly increased in both counties in the past 5 years.

Unemployment in Borsod-Abaúj-Zemplén County was higher than the other two counties of the region; the rate of under-utilization was also higher. The condition of the region's labour market had improved by year 2001 which was followed by a decline. The evolution of the curve 
suggests that the gap between vacant jobs and the unemployed is increasingly widening. One may ask why vacant jobs and unemployed people do not meet. The answer should be sought in the area of education, that is, presumably the unemployed do not have the necessary qualifications to fill the vacancies. People of working age without jobs have to prepare for higher quality expectations, which requires the re-consideration of the educational system, training and re-training programs. Many unemployed are unwilling to learn, they are not motivated enough to do so.

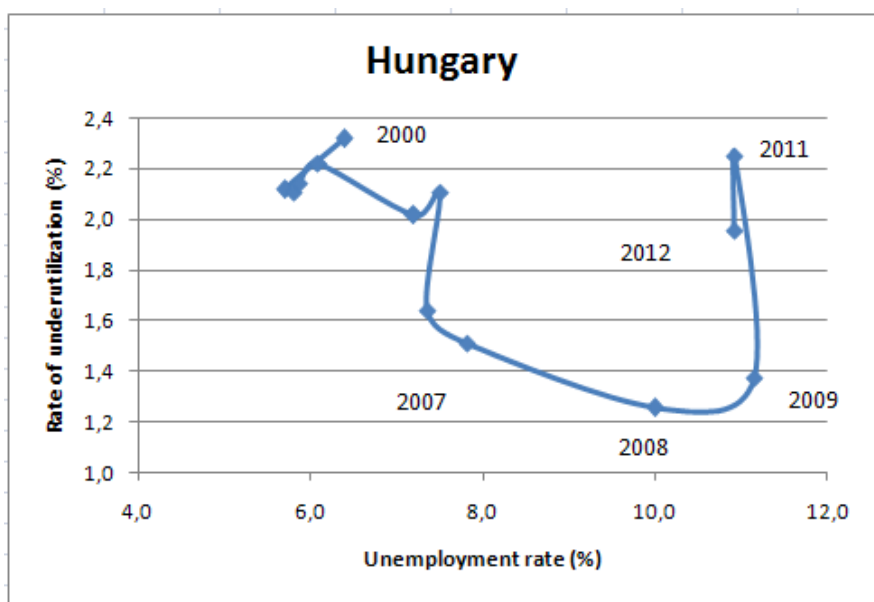

Figure 2: Evolution of Beveridge-curve between 2000 and 2012 in Hungary Source: Own work, 2013

If we analysed the Beveridge-curve in Hungary, we could observe the different way of the curve. The unemployment rate in Hungary is much more lower than in the county level, but the job vacancy rates are the same.

I analysed the priorities of National Reform Programs (NRP) in CEE countries (Figure 3). 


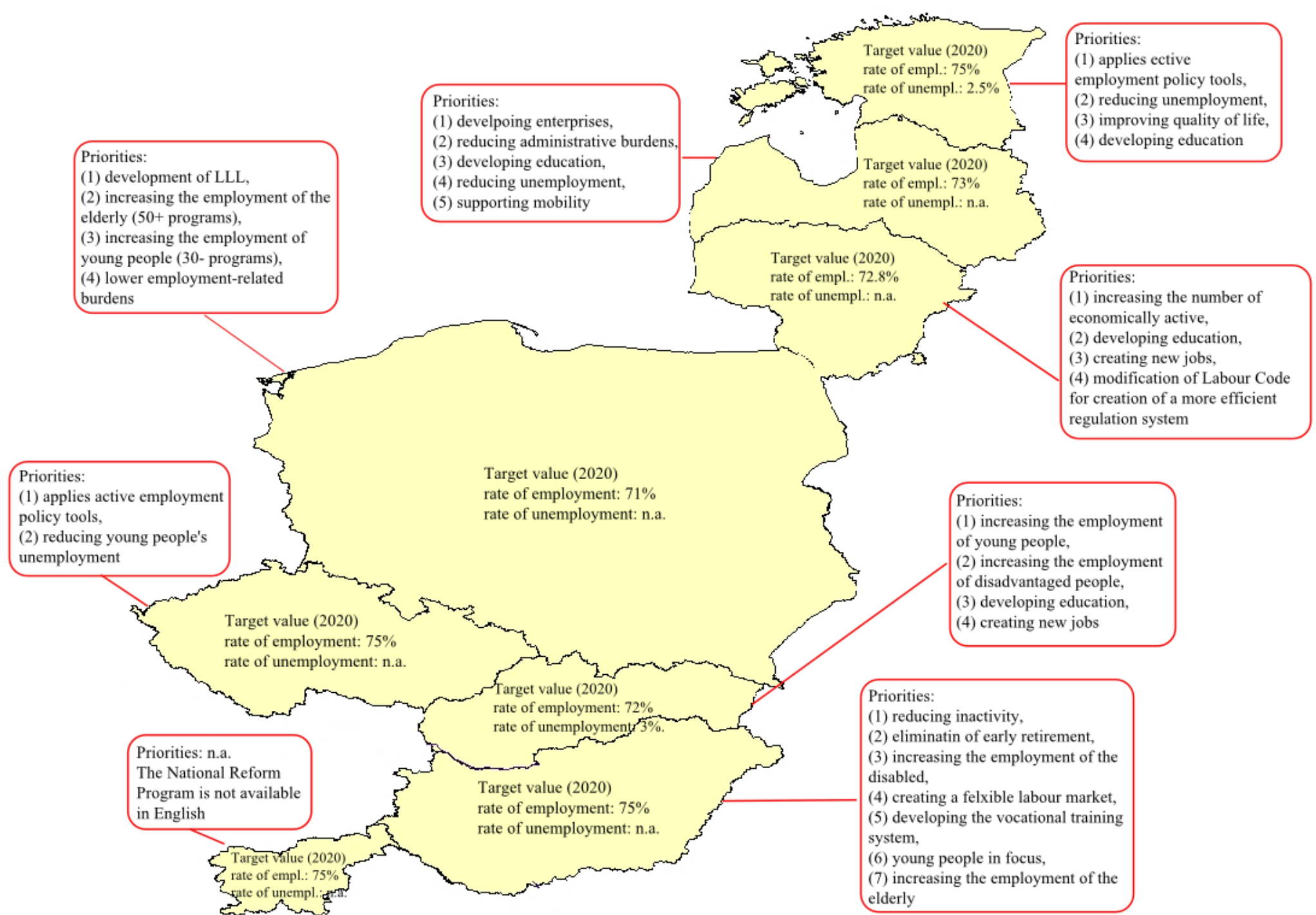

Source: NRP (2012) documents, own editing, 2013. 


\section{Employment policies of Central-Eastern European countries and the alternative labour market solutions}

The employment policy of the European Union significantly determines and sets limits on the employment-related objectives and efforts of the nation states.

The analysed NRP documents indicate that most countries views the $75 \%$ rate of employment, accepted in the Europe 2020 Strategy, as an expected and attainable criterion. The Czech Republic and Lithuania displayed target values for the employment of the elderly, other countries did not specify it. The rate of unemployment was put forth by Estonia and Slovakia, with also unrealistically low target values $(2.5-3 \%)$. The priorities mainly include the use of active employment policy tools, although in most cases the tool to be applied is not specifically named. Most country see the future development of labour market in improving the quality of life, development of education, creation of new jobs and supporting mobility. At the same time, the amounts of support or the programs assigned were not mentioned in the documents.

Employment policy aims (National Reform Programs of 2012), at the level of Central-Eastern European countries, clearly follow the main guidelines of the Europe 2020 Strategy; they hardly build upon the peculiarities and labour market demands of the particular countries. Passive tools, among employment policy tools, are dominant in this group of countries. They responded to the economic crisis with the differentiated use of active and passive tools.

The lawmakers of Hungary have significantly altered and amended several times the Code of Labour (Act 1 of year 2012) in the past period; they added cardinal changes to the Code of Labour as compared to Act 22 of year 1992. Chapter 15 of the Act includes the special rules concerning the specific types of the employment relationship, among which the followings are the classical forms of employment: fixed-term employment, telework, temporary and part-time work. Chapter 16 deals with the rules of temporary work (no significant change may be discovered as compared to the Act of 1992). In Slovakia, the No. 311/2001 Act contains the relevant rules. Currently, Slovakian government is revising the legislation because they wish to restore the institution of severance pay and other institutions safeguarding employees' interests. The Slovak law does not contain a separate provisions on atypical employment either. The Code regulates part-time work, working at home, telework, and flexible working time, that is, considerably less areas than the Hungarian one. The Slovak law does not contain references of the rules of temporary work either. Perhaps a separate chapter should have been devoted to the regulation of atypical forms of employment and to define there the most important elements concerning to all types.

Having studied the Codes of Labour of Hungary and Slovakia is can be concluded that the legal background does not provide detailed guidance concerning the regulation of atypical forms of employment in either country, which can be seen as a reason for the low proportion of these forms of employment.

\section{Necessity of the regional employment policy - conclusions}

There is no experience of regionally differentiated employment policy in Hungary. No examples can be found to this in Europe either, however, the existence of a regional employment policy with be reasonable.

The summary of the author's recommendations for the establishment of a system of criteria to underpin a regional employment policy are listed below: 
- A multi-channel employment policy would be reasonable in the long term that combines the traditional forms of employment and alternative solutions. A regional level decision is not sufficient for its realization, rather macro-level social-economic conditions have to be ensured, moreover an attitudinal change is essential. An increasing focus is placed on the application of non-traditional forms of employment due to the changing meaning of work-concept and also along with the change in the way of doing work. Future employment policies have to treat traditional and alternative forms of employment together.

- Regional employment policy should give priority to the supporting of human potential by way of, within the active employment policy tools, increasing the amount spent on labour market trainings; it requires taking the demands and emerging needs of employers.

- A strategy capitalizing on internal features and naturally taking external processes into account should be formulated instead of continuously eliminating the European Union's employment policy. The National Reform Programs of Central-Eastern European countries were also studies that did not contain country-specific features, they rather followed, with more-or less differences, the aims of the Europe 2020 Strategy in terms of the target numbers.

- The issue of employment has to be addressed in a complex manner, it is necessary to coordinate tax-policy, educational policy and other sub-policies for enhancing efficiency. This dissertation has adopted a legal-based approach; and it has tried to prove, by comparing the Labour Codes of Hungary and Slovakia, that a profound legal regulation of atypical forms of employment is not available in the countries. Therefore, it cannot be expected that the application of those types of employment is high at regional level. On the other hand, it was meant to make it understood that a complex approach is necessary to achieve the employment goals. Regional level employment could be enhanced if tax-policy and educational policy would be differentiated on the basis of employees. The results of the above mentioned Beveridge-curve call for the reconsideration of the connection between educational and employment policy.

- Developing an independent regional employment policy that sets up regional objectives and has independent measures and institutional system would be reasonable. Regional perspective is present in many areas in the European Union and this approach is getting increasingly reasonable in the case of employment and labour market as well. Regional employment policy would require independent system of measures and independent institutional system that would not be identical with the those applied in other regions of the country.

\section{References}

1. Arendt H. (2002): Vita Activa oder Vom tätigen Leben. Piper Kiadó, München, Zürich, ISBN 3-492-23623-5 http://dx.doi.org/10.1007/978-3-663-01683-0 10

2. Csoba J. (2010): A tisztes munka: A teljes foglalkoztatás: a 21. század esélye vagy utópiája? - Kísérletek a munka társadalmának fenntartására $\mathrm{s}$ a jóléti állam alapvető feltételeként definiált teljes foglalkoztatás biztosítására, L’Harmattan Kiadó, Budapest, 271 p., ISBN 978-963-236-302-8

3. Dow, J.C.R. - Dicks-Mireaux, L. (1958): The Excess Demand for Labour: A Study of Conditions in Great Britain, 1946-1956, Oxford Economic Papers, no. 10. 1-33. p., ISSN 0030-7653

4. Ékes I. (2009): Az atipikus munka és jövője. Munkaügyi Szemle, Vol. 51. No. 1. 66-71. p., ISSN 0541-3559 
5. Galasi Péter (1994): A munkaerőpiac gazdaságtana, Aula Kiadó, Budapest, 153 p.

6. Héthy, L. (2001): A rugalmas foglalkoztatás és a munkavállalók védelme; A munkavégzés új jogi keretei és következményeik a munkavállalókra. In: Frey, Mária: EUkonform foglalkoztatáspolitika, OFA, Budapest, 511 p., ISBN 963-00-9326

7. Kiss Gy. (2001): Az Európai Unió munkajoga, Osiris Kiadó, Budapest, 460 p., ISBN 963 389-540-5

8. Lipták K. (2011): Is atypical typical? - atypical employment in Central Eastern European countries, Journal for Employment and Economy in Central and Eastern Europe, Vol. 2. No 1. 1-13. p., ISSN 2191-7078

9. Rodenburg, P. (2007): The remarkable place of UV-curve in economic theory, Tinbergen Institute Discussion Paper, Amsterdam, 34 p.

\section{Acknowledgement}

„This research was realized in the frames of TÁMOP 4.2.4. A/2-11-1-2012-0001 „National Excellence Program - Elaborating and operating an inland student and researcher personal support system convergence program" The project was subsidized by the European Union, Hungary and co-financed by the European Social Fund." 